\title{
Investigation of graphite effect on the mechanical and tribological properties of Al 7075-SiC-graphite hybrid metal matrix composites
}

\author{
Atla Sridhar ${ }^{*}$, K.Prasanna Lakshmi ${ }^{2}$ \\ ${ }^{1}$ Research Scholar, JNTU Hyderabad, Telangana, 500 085, India, atla.sridhar9@gmail.com \\ 2Associate Professor, JNTU Hyderabad, Telangana, 500085, India, prasannakaujala@gmail.com \\ ${ }^{*}$ Corresponding author
}

\begin{abstract}
The aluminium metal matrix composite reinforced with ceramic material of Silicon carbide (SiC) has good mechanical properties. However, aluminium based ceramic composites require improvements in their lubrication and tribological properties. In this study an attempt is made in the development of a new material through powder metallurgy technique by the addition of Graphite, which acts as a solid lubricant. This work investigated the influence of graphite on the wear behaviour of $\mathrm{Al} 7075 / \mathrm{SiC} / \mathrm{X}$ wt.\% graphite $(\mathrm{X}=0,5$ and 10) hybrid composite. The investigation reveals the effectiveness of incorporation of graphite in the composite for gaining wear reduction. The Al 7075 (aluminium alloy 7075) reinforced with SiC -graphite were investigated. The composites were fabricated using powder metallurgy route. The microstructures, material combination, wear and friction properties were analysed by scanning electron microscopy, XRD, and pin-on-disc wear tester. The newly developed aluminium composite has significant improvements in tribological properties with a combination of $5 \%$ Silicon carbide $(\mathrm{SiC})$ and 5\% Graphite. The test reveals that sliding distance of $1000 \mathrm{~m}$ and sliding speed of $1.5 \mathrm{~m} / \mathrm{s}$ with applied load of $5 \mathrm{~N}$ result in minimum wear loss of $0.01062 \mathrm{~g}$ and coefficient of friction as 0.1278 .
\end{abstract}

Keywords: Al 7075, graphite, powder metallurgy, Metal matrix composites, Mechanical and Tribological properties.

\section{Introduction}

MMCs -Metal matrix composites possess many advantages over monolithic materials, MMCS are basically metallic alloys reinforced with mostly ceramic materials $[1,2]$. The common metallic alloys (Matrix) utilized are alloys of light weight metals.(Al, Mg and Ti). The other metallic alloys like zinc $(\mathrm{Zn})$, copper $(\mathrm{Cu})$ and stainless steel have been used.

Silicon carbide $(\mathrm{SiC})$, Alumina $\left(\mathrm{Al}_{2} \mathrm{O}_{3}\right)$, boron carbide $\left(\mathrm{B}_{4} \mathrm{C}\right)$, tungsten carbide (WC), Graphite $(\mathrm{Gr})$, carbon nano tube $(\mathrm{CNT})$ and Silica $\left(\mathrm{SiO}_{2}\right)$ are some of the synthetic ceramic particulate that has been studied. But $\mathrm{SiC}$ and Alumina are mostly utilized compared to other synthetic reinforcing particulates. Mostly all researches are focussing on improving the wear resistance of the aluminium alloy and amongst the various ceramic particles $\mathrm{SiC}$ is used with many materials and resulted in enhanced wear resistance $[3,11,15]$. SiC particulates reinforced AMCs are well-known for high strength and wear resistance compared to traditional alloys $[4,16]$. Increase in volume of $\mathrm{SiC}$ and its size decreases the specific wear rate of AA6061/SiC composites [5-7]. Both mechanical strength and wear resistance of $\mathrm{Al}$ alloy increases with increase in $\mathrm{SiC}$ particulates $[18,19]$. However, the consequent increase in $\mathrm{SiC}$ content in compo- sites makes machining difficult. Self lubricating (Gr, $\left.\mathrm{MoS}_{2}\right)$ particulates are well suited to this application, and their addition improves the machinability and wear resistance of Al-SiC composites $[8,9,20,21]$.

The aim of this study was to fabricate aluminium matrix hybrid composite reinforced with both hard and soft solid lubricant nano-particles by mechanical milling and powder metallurgy techniques, and to examine the dry sliding wear behaviour of the produced nano-composite. The microstructures of produced composites were executed using of X-ray diffraction measurements (XRD), optical microscopy (OM), scanning electron microscopy (SEM), and mechanical properties were measured through density and hardness tests.

\section{Materials}

In the present work Al7075 alloy has been selected as the base matrix and $\operatorname{SiC}(27-33 \mu \mathrm{m})$ as reinforcing material with the composition of $\mathrm{Al} 7075$ - 5 wt. \% SiC - X wt.\% Gr(X $=0,5,15$ wt. \%). The Matrix material (supplied by Prabhu Copper Restricted, Mumbai, and Maharashtra, India, 99.8\% purity) used in the present experimental investigation is Aluminium 7075 (Al 7075). The composites were processed by powder metallurgy route. 


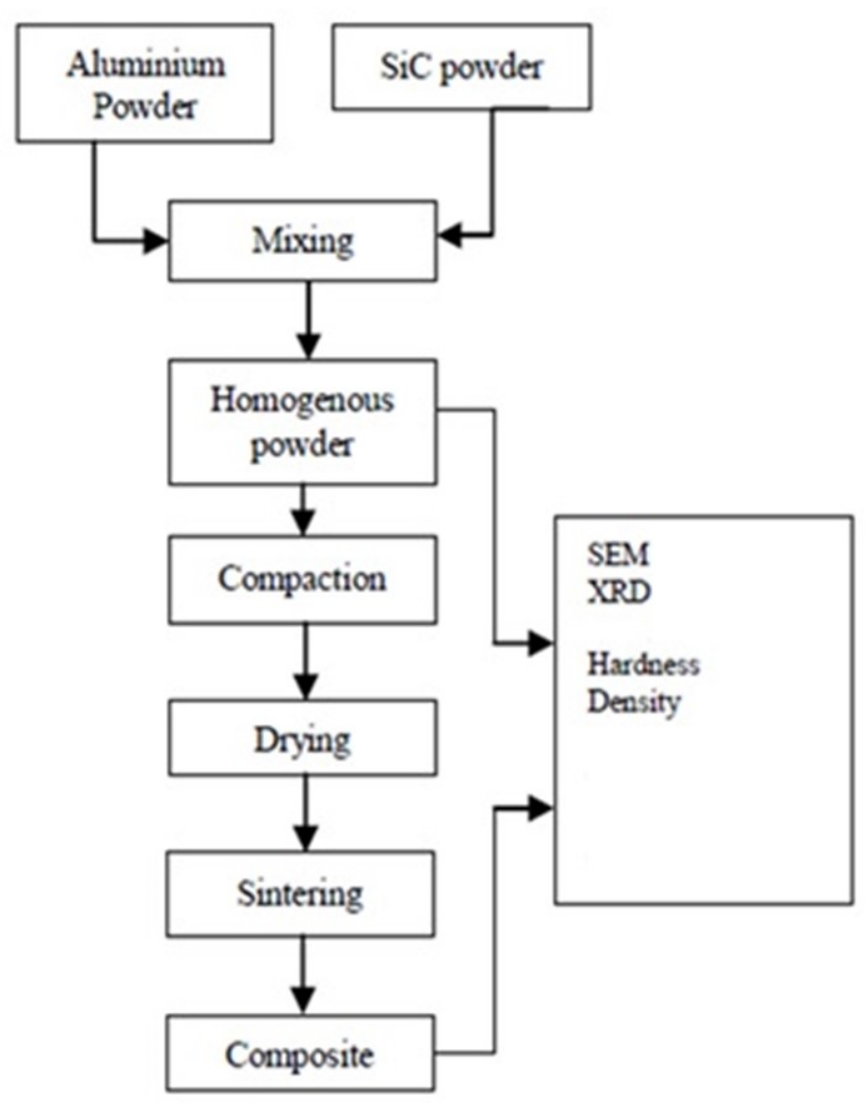

Figure 1. Powder metallurgy process chart

Powder metallurgy (PM) is a metal working process for forming precision metal components from metal powders. The metal powder is first pressed into product shape at room temperature. This is followed by heating (sintering) which causes the powder particles to fuse together without melting as shown in Fig.1. The parts produced by PM have adequate physical and mechanical properties while completely meeting the functional performance characteristics. Industrial applications of PM parts include self - lubricating bearings, porous metal filters and a wide range of engineered shapes, such as gears, cams, brackets, sprockets, etc.

\section{Experimental procedure}

\section{Specimen Preparation:}

At first, the received powders were dried at $110{ }^{\circ} \mathrm{C}$ in a muffle furnace for $1 \mathrm{hr}$ to remove the moisture and other contaminations present. In the PM process the following three steps are followed in sequence: mixing (or blending), compacting, and sintering. Blending/Mixing: A homogeneous mixture of elemental metal powders or alloy powders is prepared.

\section{Blending:}

Blending of the powders was performed in a high energy planetary ball mill machine in the Laboratory as shown in Fig.2. Mechanical alloying is performed for $60 \mathrm{hrs}$, duly

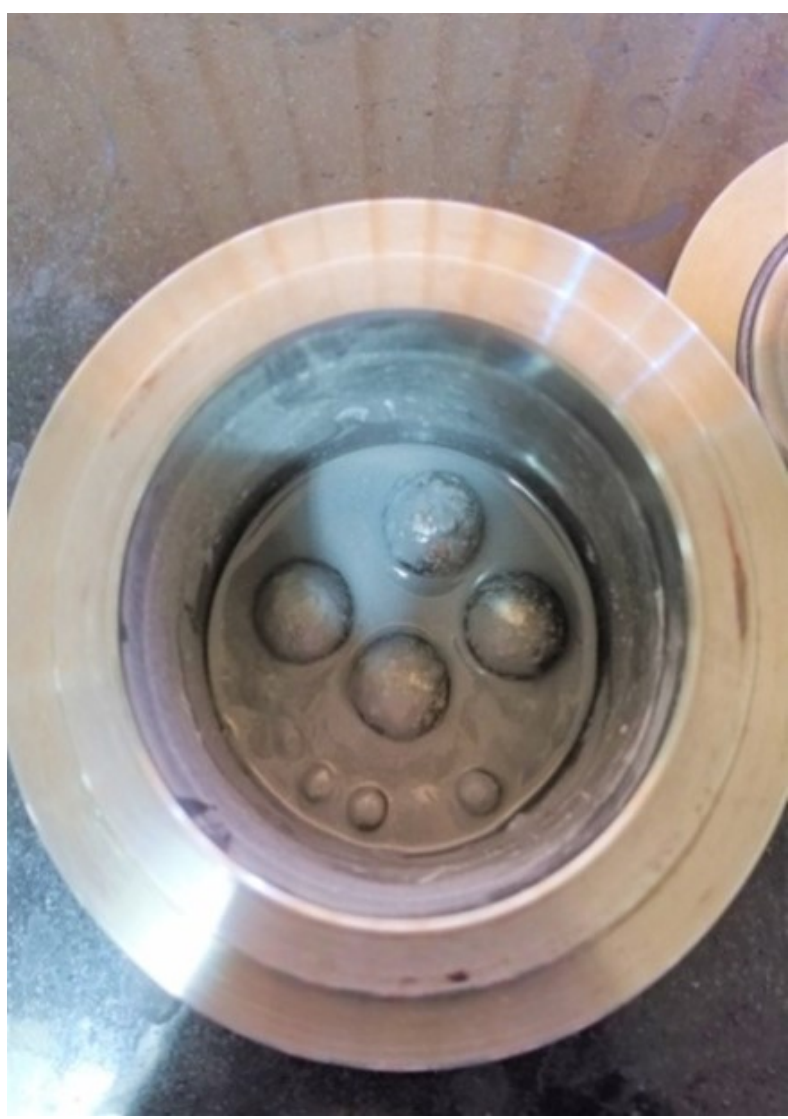

Figure 2. Ball mill powder in toluene medium

maintaining the conditions such as ball to powder weight proportion of 10:1, speed of $300 \mathrm{rpm}$ and cycle time for 5 $\min$.

\section{Compacting:}

A controlled amount of the mixed powder is introduced into a precision die and it is pressed or compacted at a pressure range of $700 \mathrm{MPa}$ a shown in Fig. 3. The compacting pressure required depends on the characteristics and shape of the particles, the method of mixing, and on the lubricant used. This is generally done at room temperature. In doing so, the loose powder is consolidated and densified into a shaped model. The mould is called "green compact." As is comes out of the die, the compact has the size and shape of the finished product. The strength of the compact is just sufficient for in - process handling and transportation to the sintering furnace.

This process involves heating of the material, usually in a controlled atmosphere, to a temperature below the melting point of the major constituent during this process the metal becomes soft and the reinforcement and matrix material fuse together. Further special finishing processes can be carried out but usually the part made by powder metallurgy does not require extra finishing processes. The required specimens obtained as shown in Fig.4.

The prepared samples were examined using Scanning electron microscope (SEM), which is an essential investigative apparatus and performs qualitative metallographic 


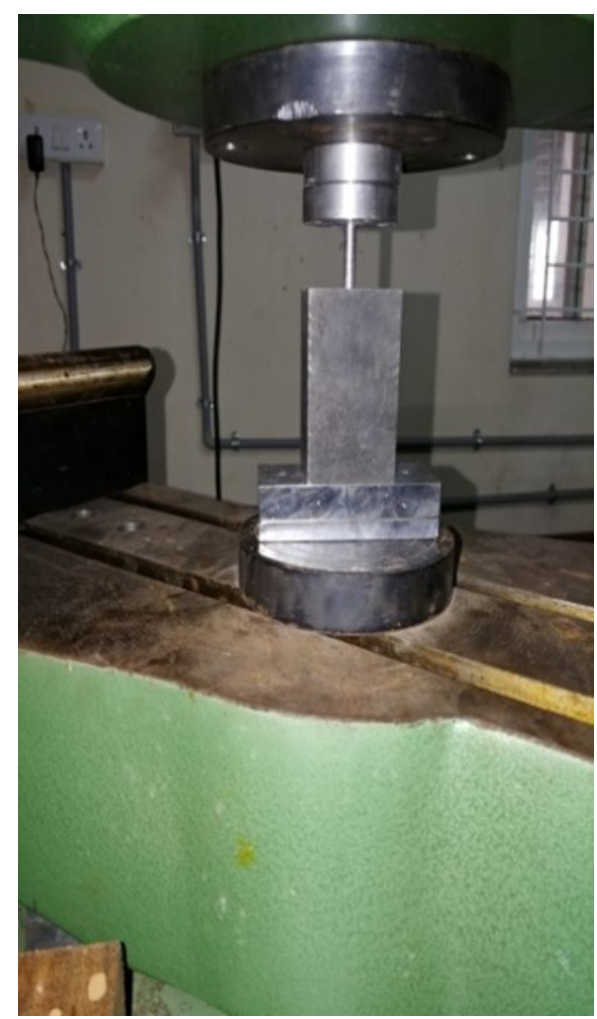

Figure 3. Uni-axial compaction under UTM

examination. The micro graphs produced by SEM reveal grain structures, particles' size, shape and their dispersion.

\section{Density and hardness:}

The density of the composites specimens was analyzed by the rule of mixture. The specimens were measured first in air and afterward water and density values were calculated. Similar results were observed by [10, 13, 17, and 19]. Hardness test was performed on Rockwell hardness analyzer. Every specimen was subjected to hardness test with 1/16th ball indenter, $100 \mathrm{Kgf}$ load and 20 seconds of dwell time. Trials were directed for varying weight percentage of $\mathrm{SiC}$ reinforcement.

\section{Dry sliding behaviour:}

Tribological behaviours of the specimens were studied by conducting the dry sliding wear test as per the standard full factorial method. The wear parameters selected for the experiment were sliding speed in meter per second $(\mathrm{m} / \mathrm{s})$, load in Newton $(\mathrm{N})$ and sliding distance in meter $(\mathrm{m})$. The non-linear behaviour of the process parameters, if exists, can only be revealed when more than two levels of the parameters are investigated. Therefore, each parameter was analyzed at three levels and process parameters along with their values at three levels are given in Table 1.

The dry sliding wear tests were conducted on a pin-ondisc wear testing machine (Model: TR 20LE, DUCOM) according to the ASTM: G99-05 Standard. Tests were carried out in ambient temperature without any lubrication. Specimens of size $6 \mathrm{~mm}$ diameters and $30 \mathrm{~mm}$ length were cut
Table 1. Levels for various process parameters

\begin{tabular}{llll}
\hline Parameter & Level 1 & Level 2 & Level 3 \\
\hline Load (N) & 5 & 10 & 15 \\
Sliding speed & 0.5 & 1 & 1.5 \\
$(\mathrm{~m} / \mathrm{s})$ & & & \\
Sliding distance & 1000 & 2000 & 3000 \\
$(\mathrm{~m})$ & & & \\
\hline
\end{tabular}

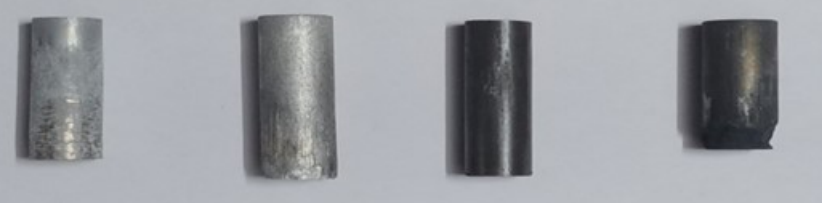

Figure 4. Prepared composite specimens

from the sintered samples machined and then were polished. The contact surface of the prepared sample (pin) has to be flat and should be in contact with the rotating disk. During the test, the pin is held pressed against a rotating EN32 steel disc (hardness of 70 HRC) by applying load that acts as counter weight and balances the pin. The track diameter was changed for all experiments in the range of 60$120 \mathrm{~mm}$ and the parameters such as the Load, sliding speed and sliding distance were changed in the range given in Table 1.

A LVDT (load cell) on the lever arm helps to determine the wear at any point of time by monitoring the movement of the arm. Once the surface in contact wears out, the load pushes the arm to remain in contact with the disc. This movement of the arm generates a signal, which was used to determine the maximum wear. Weight loss of each specimen was obtained by weighing the specimen before and after the experiment by a single pan electronic weighing machine with an accuracy of $0.0001 \mathrm{~g}$ after thorough cleaning with acetone solution. The specific wear rate $\left(\mathrm{mm}^{3} / \mathrm{N}-\right.$ m) was then expressed on 'mass loss' bases

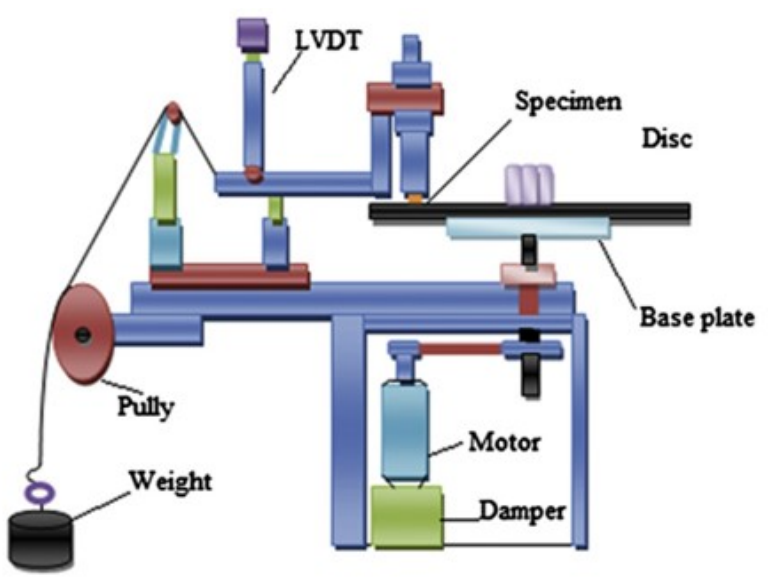

Figure 5. Schematic view of the pin-on-disc apparatus used in the study 
(a)

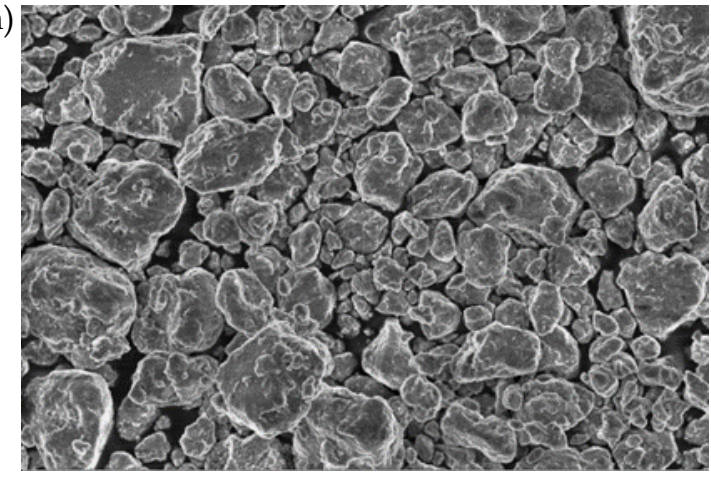

(b)

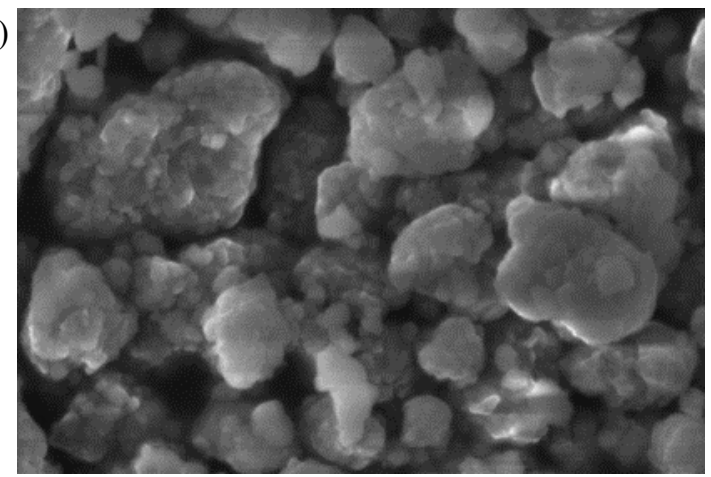

(c)

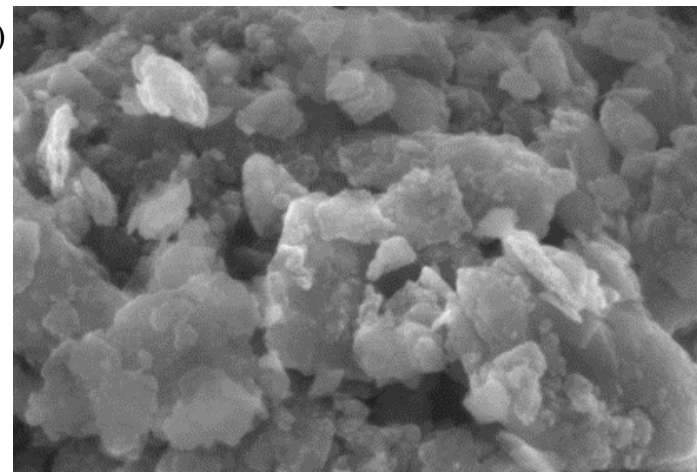

(d)

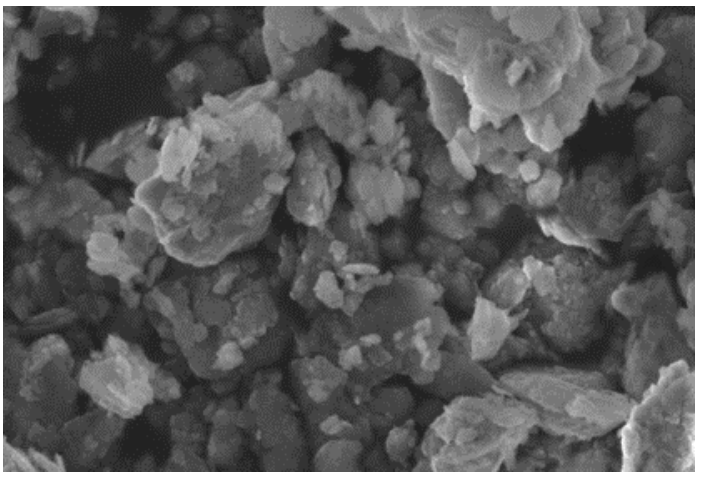

Figure 6 (a-d). SEM micrographs of sintered composites (a) Al 7075, (b) Al 7075 -5\% SiC, (c) Al 7075-5 SiC-5\% Gr, (d) $\mathrm{Al} 075-5 \mathrm{SiC}-10 \% \mathrm{Gr}$

$$
\mathrm{K}_{\mathrm{s}}=\frac{\Delta \mathrm{M}}{\rho L \mathrm{~F}_{\mathrm{N}}}
$$

Where Ks is the specific wear rate $\left(\mathrm{mm}^{3} / \mathrm{N}-\mathrm{m}\right), \mathrm{DM}$ is the mass loss in the test duration $(\mathrm{g}), \mathrm{q}$ is the density of the composite $\left(\mathrm{g} / \mathrm{cm}^{3}\right), \mathrm{L}$ is the sliding velocity and $\mathrm{F}_{\mathrm{N}}$ is the average normal load $(\mathrm{N})$. The schematic view of the pin-on -disc apparatus used in the study is shown in Fig.5.

\section{Results and discussion}

\section{SEM Analysis:}

The polished specimen images were captured in the scanning electron microscopy with various magnification and scale. Figs. 6 (a-d) represent the SEM image of hybrid composite of $\mathrm{Al} 7075, \mathrm{Al} 7075+5 \% \mathrm{SiC}, \mathrm{Al} 7075+5 \% \mathrm{SiC}$ $+5 \% \mathrm{Gr}$ and $\mathrm{Al} 7075+5 \% \mathrm{SiC}+10 \% \mathrm{Gr}$ respectively. The image reveals uniform mixture of $\mathrm{Al} 7075, \mathrm{SiC}$ and the evenly distributed graphite over base alloy matrix. The image with minimum dark zone reveals the minimum porosity formation level in the specimen.

\section{XRD Analysis:}

The X-ray diffraction (XRD) results for the prepared nano composites are shown in Fig.7. These results indicate the presence of aluminium (in the largest peaks), and the presence of silicon carbide particles and carbon is indicated by minor peaks. A clearly visible carbon peak can be observed in the hybrid composites. The increase in the intensity of the carbon peaks with the increasing graphite content of the composite is evident. A gradual marginal shift

of the $\mathrm{Al}$ peaks to higher angles with an increase in the weight $\%$ of the graphite content is also evident. Fig. 5 shows that there is no oxygen reaction in the samples during the sintering process. The phases identified by XRD analysis were similar for all hybrid nano-composites. These patterns show that reinforcement particles are well distributed in the aluminium matrix. The XRD pattern confirmed the presence of aluminium, $\mathrm{Gr}(\mathrm{C})$ and $\mathrm{SiC}$ particles in the hybrid nano-composite

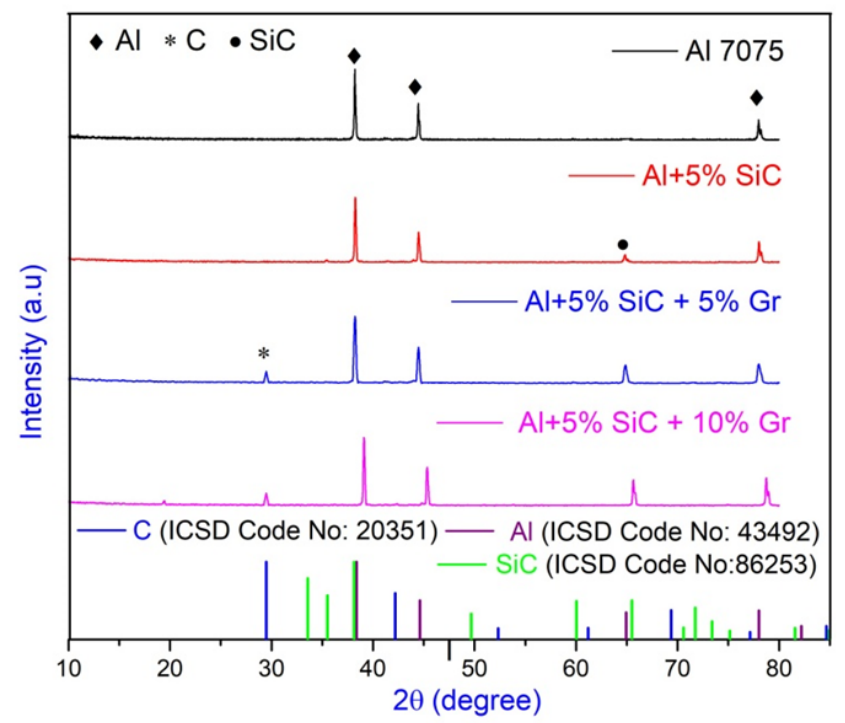

Figure 7. XRD analysis 


\section{Density (g/cc)}

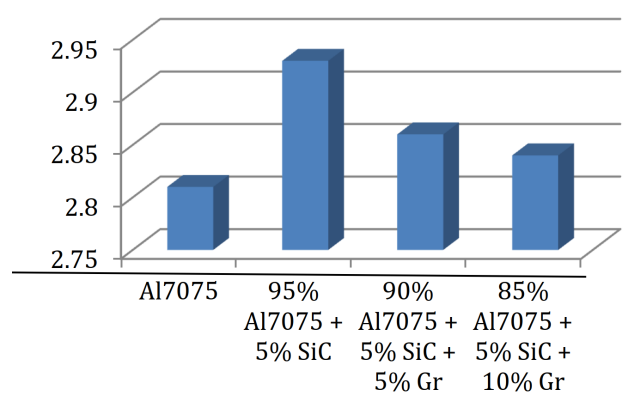

Figure 7.

\section{Density and hardness:}

It can be observed from Table 2, that the density of composites are higher than that of the base matrix, further, the density increases with increased percentage of filler content in the composites. This increase in density of the Al 7075-SiC composites is mainly attributed to the higher density of SiC than that of the Al7075. The density of the Al 7075-SiC composite material increased as the $\mathrm{SiC}$ content increased.

Table 2. Mechanical properties

\begin{tabular}{|c|c|c|c|}
\hline S.No & Composition & $\begin{array}{l}\text { Theoretical Density } \\
(\mathrm{g} / \mathrm{cc})\end{array}$ & $\begin{array}{l}\text { Hardness } \\
\text { HRB }\end{array}$ \\
\hline 1 & Al7075 & 2.81 & 74 \\
\hline 2 & $\begin{array}{l}95 \% \text { Al7075 + 5\% } \\
\text { SiC }\end{array}$ & 2.93 & 77 \\
\hline 3 & $\begin{array}{l}90 \% \text { Al7075 + 5\% } \\
\mathrm{SiC}+5 \% \text { Gr }\end{array}$ & 2.86 & 73 \\
\hline 4 & $\begin{array}{l}85 \% \text { Al7075 + 5\% } \\
\text { SiC + 10\% Gr }\end{array}$ & 2.84 & 68 \\
\hline
\end{tabular}

From the constructed Graph Fig. $7 \& 8$ shows that, it also observed that there is a decrease in density with increase in Gr reinforcement. This can be attributed to the addition of lower density reinforcements of Gr. It can be understood that the hardness of the composites was worse with the increase in weight percent of Gr reinforcements.

The decrease in hardness of hybrid composite is due to the following reasons. (i) Low hardness of Gr reinforcement particles. (ii) Uniform distribution of $\mathrm{Gr}$ in the nano composites. (iii) The decreased density that contributes to the decrease in hardness.

\section{Sliding wear behaviour:}

The wear and coefficient of friction properties were analysed by pin-on-disc equipment with the testing parameter ranges of applied loads of 5-15 N, varying sliding distance of $1000-3000 \mathrm{~m}$ and sliding speeds of $0.5-1.5 \mathrm{~m} / \mathrm{s}$. The pin-on-disc equipment was operated with constant sliding speed of $0.5 \mathrm{~m} / \mathrm{s}$ and constant sliding distance of $1000 \mathrm{~m}$ to calculate the wear loss. The wear loss and coeffi-

\section{Hardness HRB}

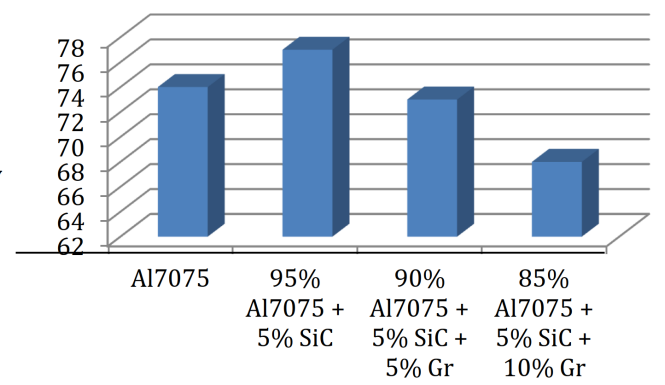

a Hardness HRB

Figure 8.

cient of friction were calculated for $\mathrm{Al} 7075+5 \% \mathrm{SiC}, \mathrm{Al}$ $7075+5 \% \mathrm{SiC}+5 \% \mathrm{Gr}$ and $\mathrm{Al} 7075+5 \% \mathrm{SiC}+5 \% \mathrm{Gr}$ for three ranges of applied load.

The wear loss increased with respect to the applied load for all the three combinations of specimen. The minimum wear loss of $0.01395 \mathrm{~g}$ and minimum coefficient of friction of 0.1476 are attained by $\mathrm{Al}+5 \% \mathrm{SiC}+5 \% \mathrm{Gr}$ specimen at applied load of $5 \mathrm{~N}$.

Figure 9(a) indicates specimen behaviour for wear loss versus applied load, and the wear loss increases with applied load for all three combinations. Similarly, Figure 9(b) shows the relationship between coefficient of friction and applied load, and the coefficient of friction increased correspondingly with applied load. The wear loss and coefficient of friction results under constant applied load of $5 \mathrm{~N}$ and sliding distance of $1000 \mathrm{~m}$ are presented in Table. 4 The wear loss and coefficient of friction were found minimum in high sliding speed and graphs and are mentioned in Figure 9(c) and 9(d) respectively. The minimum wear loss of $0.00918 \mathrm{~g}$ and minimum coefficient of friction of 0.1053 are found for $\mathrm{Al}+5 \% \mathrm{SiC}+5 \%$ Gr specimen at sliding speed of $1.5 \mathrm{~m} / \mathrm{s}$.

In higher sliding velocity, the adhesion wear is found and at minimum sliding distance, protective layer for the composite is formed by oxide layer on the surface which develops high cohesive forces to the contact surfaces. Heat generation increased with increasing sliding speed during friction contact. The aluminium matrix tends to plastic deformation and leads to form an oxide surface at the elevated temperature, it permits smooth sliding on the disc surface and wear loss is reduced at higher speed.

\section{Conclusion}

The different types of Aluminium hybrid composites developed by powder metallurgy are studied in this project work. The introduction of Gr as solid lubricant has produced significant tribological performance. In the studied combinations of $\mathrm{Al}+5 \% \mathrm{SiC}, \mathrm{Al}+5 \% \mathrm{SiC}+5 \% \mathrm{Gr}$ and $\mathrm{Al}$ $+5 \% \mathrm{SiC}+10 \% \mathrm{Gr}$, wear and friction properties depended up on the percentage of $\mathrm{Gr}$. The combination of $\mathrm{Al}+5 \%$ $\mathrm{SiC}+5 \% \mathrm{Gr}$ has minimum wear and coefficient of friction at constant sliding speed of $0.5 \mathrm{~m} / \mathrm{s}$ and constant sliding distance of $1000 \mathrm{~m}$. Similarly, the minimum wear and coef- 

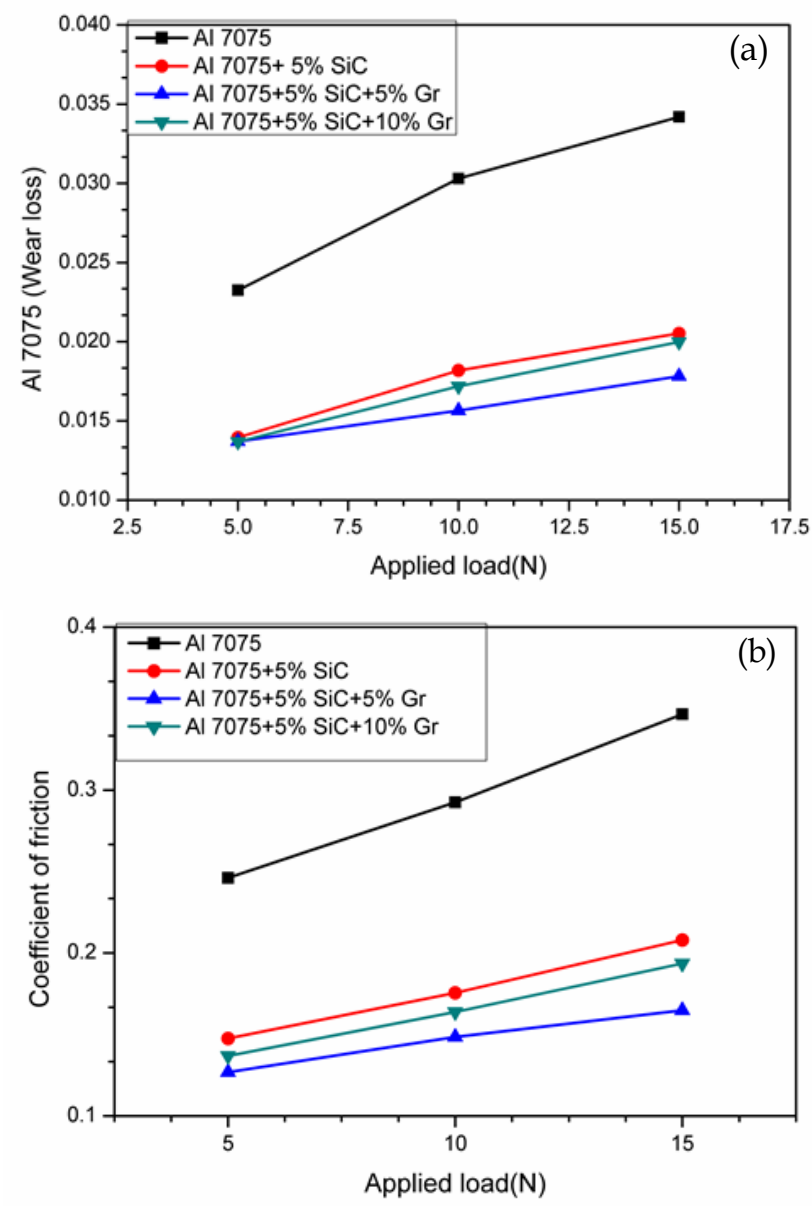
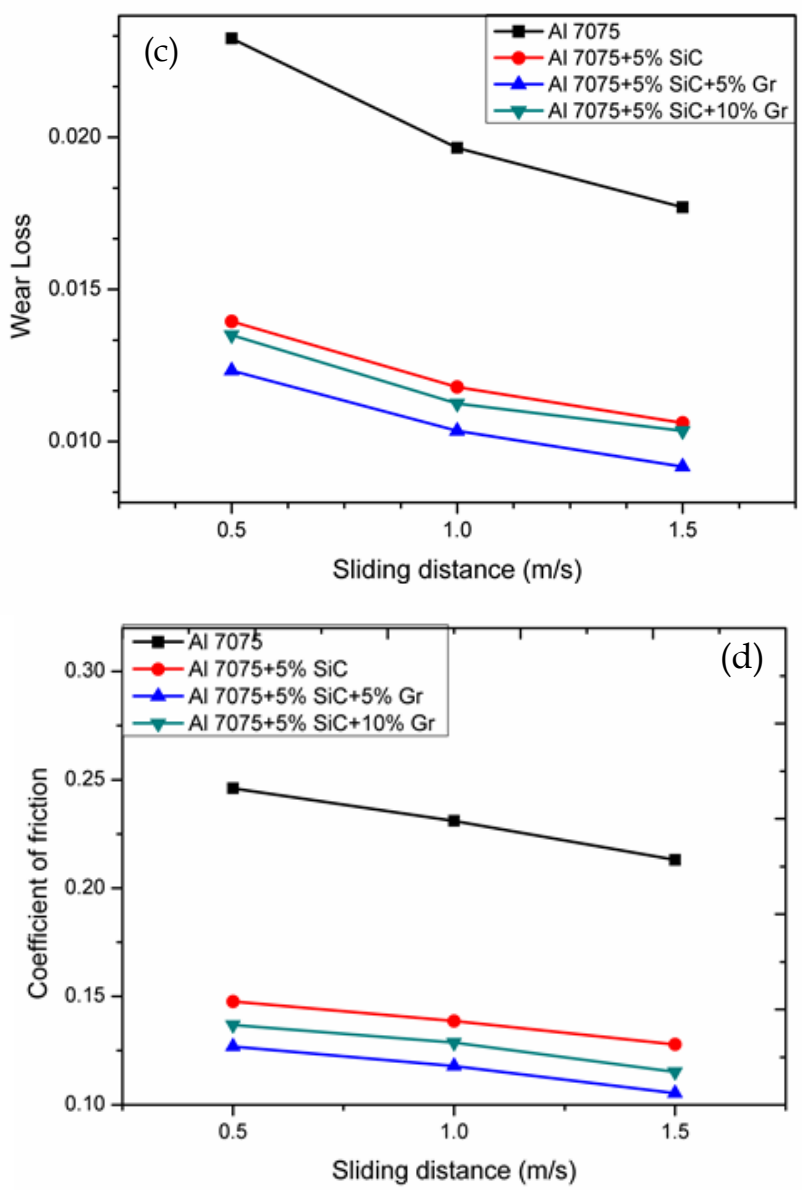

Figure 9(a-d): (a)wear loss Vs applied load, (b): coefficient of friction Vs Applied load, (c) waer loss Vs sliding distance, (d) coefficient of friction Vs sliding distance.

ficient of friction were observed at sliding speed of $1.5 \mathrm{~m} / \mathrm{s}$ with content applied load of $5 \mathrm{~N}$ and sliding distance of $1000 \mathrm{~m}$. The study reveals that further addition of $10 \% \mathrm{Gr}$ in the hybrid composite does not help to improve the tribological property. The design of experiment may be extended to optimise the composition and tribological property as the scope of work in future.

\section{Acknowledgements}

I express my deep sense of regard and gratitude to my Supervisor, Dr. K. Prasanna Lakshmi, HOD of MED, JNTU college of Engineering, Manthani, Telangana, India, for effective advice, guidance and constant encouragement. I also wish to thank each and every one who helped me directly or indirectly, in carrying out different experiments like UTM, Sintering, SEM and XRD, etc.

\section{References}

[1] K. Umanath, K. Palanikumar, and S. T. Selvamani, "Analysis of dry sliding wear behaviour of Al6061/ $\mathrm{SiC} / \mathrm{Al} 2 \mathrm{O} 3$ hybrid metal matrix composites," Compos. Part B Eng., vol. 53, pp. 159-168, 2013. https:// doi.org/10.1016/j.compositesb.2013.04.051

[2] Siddesh Kumar N G, G S Shiva Shankar,
S.Basavarajappa, "Comparative Study on Dry Sliding Wear Behaviour of Metal Matrix Hybrid Composites at Room and High Temperature," Int. J. Eng. Res. Adv. Technol., vol. 01, no. 01, pp. 16-24, 2015.

[3] G. Singh and S. Goyal, "Dry sliding wear behaviour of AA6082-T6/SiC/B4C hybrid metal matrix composites using response surface methodology," Proc. Inst. Mech. Eng. Part L J. Mater. Des. Appl., vol. 0, no. 0, pp. 1-13, 2016. https:// doi.org/10.1177/1464420716657114

[4] Kumar S, Balasubramanian V. Developing a mathematical model to evaluate wear rate of AA7075/SiCp powder metallurgy composites. Wear 2008;264:102634. https://doi.org/10.1016/j.wear.2007.08.006

[5] Sahin Y. Tribological behaviour of metal matrix and its composite. Mater Des 2007;28:1348-52. https:// doi.org/10.1016/j.matdes.2006.01.032

[6] T jong SC. Processing and deformation characteristics of metals reinforced with ceramic nanoparticles. In: Tjong S-C, editor. Nano crystalline materials, 2nd ed. Oxford: Elsevier; 2014. pp. 269-304. https:// doi.org/10.1016/B978-0-12-407796-6.00008-7 
[7] Rino JJ, Chandramohan D, Sucitharan KS, Jebin VD. Anoverview on development of aluminium metal matrix composites with hybrid reinforcement. IJSR India Online ISSN 2012:2319-7064.

[8] Das DK, Mishra PC, Singh S, Pattanaik S. Fabrication and heat treatment of ceramic-reinforced aluminium matrix composites - a review. Int J Mech Mater Eng 2014; 9(1):pp. 1-15. https://doi.org/10.1186/s40712014-0006-7

[9] Casati R, Vedani M. Metal matrix composites reinforced bynano-particles-a review. Int journal of Metals 2014; 4(1):pp. 65-83. https://doi.org/10.3390/ $\underline{\text { met4010065 }}$

[10] Alaneme KK, Olubambi PA. Corrosion and wear behaviour of rice husk ash-alumina reinforced AlMg-Si alloy matrix hybrid composites. IntJ Mater Res Technol 2013; 2(2):pp. 188-94. https:// doi.org/10.1016/j.jmrt.2013.02.005

[11] Lee HS, Yeo JS, Hong SH, Yoon DJ, Na KH. The fabrication process andmechanical properties of $\mathrm{SiCp} /$ Al-Si metal matrix composites for automobileairconditioner compressor pistons. J Mater Process Technol, 2001; pp. 202-208. https://doi.org/10.1016/ S0924-0136(01)00680-X

[12] Alumina reinforced AA 6063 metal matrix composites developed by two step stir casting process. ActaTechCorvininesis - Bull Eng 2013; 6(3): pp. 245-254.

[13] Alaneme KK, Aluko AO. Fracture toughness (K1C) and tensile properties of as-cast and age-hardened aluminium (6063) -silicon carbide particulate composites. Sci Iran2012; 19(4): pp. 992-996. https:// doi.org/10.1016/j.scient.2012.06.001

[14] SirahbizuYigezu B, Mahapatra MM, Jha PK. Influence of reinforcement type on microstructure, hardness, and tensile properties of an aluminum alloy metal matrix composite. J Miner Mater CharactEng 2013; 1(4): pp. 124-130. https://doi.org/10.4236/ jmmce.2013.14022

[15] Oghenevweta JE, Aigbodion VS, Nyior GB, Asuke F. Mechanical properties and microstructural analysis of Al-Si-Mg/carbonized maize stalk waste particulate composites.

[16] Bhandakkar A, Prasad RC, Sastry SM. Fracture toughness of AA2024 aluminum fly ash metal matrix composites. Int J Composite Materials 2014; 4(2): pp. 108-124.

[17] Shivaraja HB, Kumar BP. Experimental determination and analysis of fracture. Toughness MMC 2014; 3(7): pp. 888-892.

[18] Alaneme KK, Bodunrin MO. Mechanical behaviour of alumina reinforced AA 6063 metal matrix composites developed by two step - stir casting process.
Acta Tech Corvininesis - Bull Eng 2013; 6(3): pp. 105110.

[19] Alaneme KK, Aluko AO. Production and agehardening behaviour of borax premixed $\mathrm{SiC}$ reinforced Al-Mg-Si alloy composites developed by double stir-casting technique. West Indian J Eng 2012; 34 (1-2): pp. 80-85.

[20] Alaneme KK. Corrosion behaviour of heat-treated Al $-6063 / \mathrm{SiCp}$ composites immersed in $5 \mathrm{wt} \% \mathrm{NaCl}$ solution. Leonardo Journal of Science 2011; 18(18): pp. 55-64.

[21] Bobi'c B, Mitrovi 'c S, Babi'c M, Bobi'c I. Corrosion of metal-matrix composites with aluminium alloy substrate. TribolInd 2010; 32(1): pp. 3-11.

[22] M.L. TedGuo, C.Y.A. Tsao, Tribological behavior of self-lubricating aluminium/SiC/graphite hybrid composites synthesized by the semi- solid powderdensification method, Composites Science and Technology 60 (2000); pp. 65-74. https:// doi.org/10.1016/S0266-3538(99)00106-2

[23] Poovazhagan L, Kalaichelvan K, Rajadurai A, Senthilvelan V. Characterization of hybrid silicon carbide and boron carbide nanoparticles-reinforced aluminum alloy composites. Procedia Eng2013; pp. 681-689. https://doi.org/10.1016/ j.proeng.2013.09.143 